\title{
Interactions of wind-transported snow with a rift in the Ross Ice Shelf, Antarctica
}

\author{
Katherine C. Leonard, ${ }^{1}$ L.-Bruno Tremblay, ${ }^{1,2}$ Douglas R. MacAyeal, ${ }^{3}$ and Stanley S. Jacobs ${ }^{1}$ \\ Received 18 December 2007; accepted 29 January 2008; published 14 March 2008.
}

[1] Rifts in ice shelves accumulate a mélange of snow and firn from above and marine ice from below, material that has been postulated to negatively influence iceberg calving. From measurements and modeling we show that a $100 \mathrm{~m}$ wide rift near the front of the Ross Ice Shelf captures all wind-transported snow traveling in saltation and a substantial fraction of the snow blowing in suspension across the rift. Moderate winds and snow transport appear sufficient to fill the rift in several years, whereas the mélange surface profile remains relatively constant within the $30 \mathrm{~m}$ deep rift. Observed subsidence and ocean temperatures in the rift suggest that net basal melting dissolves the mélange from below, limiting its effectiveness as an anti-calving agent near ice fronts. Citation: Leonard, K. C., L.-B. Tremblay, D. R. MacAyeal, and S. S. Jacobs (2008), Interactions of wind-transported snow with a rift in the Ross Ice Shelf, Antarctica, Geophys. Res. Lett., 35, L05501, doi:10.1029/2007GL033005.

\section{Iceberg Calving Rifts and Ice Mélange}

[2] Rifting of ice shelves and calving of icebergs occur under all environmental conditions that support the existence of Antarctic ice shelves. Recent observations along the Antarctic Peninsula [Rott et al., 1996] indicate that iceberg calving rates can accelerate rapidly under conditions of atmospheric warming [Scambos et al., 2000]. Hulbe et al. [2004] suggested that sudden ice shelf collapse similar to the 2002 disintegration of Larsen B may have been a feature of past abrupt climate change events. Understanding the mechanisms that govern iceberg calving in the comparatively stable, present-day climate of the Ross Sea may shed light on such hypotheses and help to predict the response of modern ice shelves to future climate changes.

[3] Ice mélange describes the mixture of marine ice, pieces of broken ice shelf, and windblown snow that forms the floor of through-cutting rifts in modern-day ice shelves. It has been postulated that mélange may impede rift propagation and iceberg calving [Hulbe et al., 1998; Rignot and MacAyeal, 1998]. Significantly thinner than the surrounding ice shelf, and with seasonally variable characteristics, mélange may respond more rapidly than shelf ice to climate warming

\footnotetext{
${ }^{1}$ Lamont-Doherty Earth Observatory, Palisades, New York, USA.

${ }^{2}$ Department of Atmospheric and Oceanic Sciences, McGill University, Montreal, Quebec, Canada.

${ }^{3}$ Department of Geophysical Sciences, University of Chicago, Chicago, Illinois, USA.
}

Copyright 2008 by the American Geophysical Union. 0094-8276/08/2007GL033005
[Fricker et al., 2005a; Larour et al., 2004]. Despite these indications that mélange may modulate iceberg calving rates, its evolution as a component of ice-shelf rift systems has yet to be fully evaluated.

[4] One undetermined aspect of ice mélange is the relation between its composition and the accumulation and attrition mechanisms that will evolve with climate change. Here we compare the extent to which mélange may be fed by wind transport of snow in the atmosphere with observations in and near a rift in the Ross Ice Shelf (Figure 1). The rift is located on the eastern edge of the area affected by the Ross Ice Shelf Air Stream (RAS), a persistent southerly, partly katabatic-origin surface wind [Carrasco and Bromwich, 1993; Parish et al., 2006], in a region where net accumulation is between $0.16-0.18 \mathrm{~m} \mathrm{a}^{-1}$ weq [Schwerdtfeger, 1984]. This rift has also been monitored by an automated weather station (AWS) since 2004, and webcam in 2004-2005.

\section{Wind Transport of Snow}

[5] Blowing and drifting snow are persistent features of the Antarctic environment [King and Turner, 1997]. Snow can be mobilized by the wind (Figure 2, top) when the surface shear stress rises above some critical value that depends on snow surface morphology (grain size, density, presence of crust, etc.) and air temperature. A typical 10 meter wind speed threshold for mobilizing snow in Antarctica may be around $5 \mathrm{~m} \mathrm{~s}^{-1}$ [Mahesh et al., 2003]. Once in motion, snow may bounce along the surface via saltation, a mode of sediment transport wherein particles too large to enter suspension follow ballistic trajectories of up to $\sim 10 \mathrm{~cm}$ high, or be lofted into suspension by entrainment in turbulent eddies. Due to the distribution of particle sizes that make up a snow pack, and the changing of that distribution due to sublimation and re-deposition of moisture, these two transport mechanisms are interactive. A common distinction between drifting (mostly saltating) and blowing (mostly suspended) snow is based on the degree to which an observer's visibility is obscured by the snow particles in suspension at the $2 \mathrm{~m}$ height. As strong winds suspend more snow particles, at greater elevations, "blowing" snow can transport more mass per unit time than "drifting" snow.

[6] While much of the Antarctic continent experiences wind speeds at or above the threshold for wind transport of snow for more than $50 \%$ of an average year, the presence of blowing snow requires that loose snow be available on the upstream surface. Weather observations show that blowing snow occurs during $34 \%$ of the year ( $42 \%$ of the winter months) near the south pole [Mahesh et al., 2003], and between 27 and $37 \%$ of the time in 


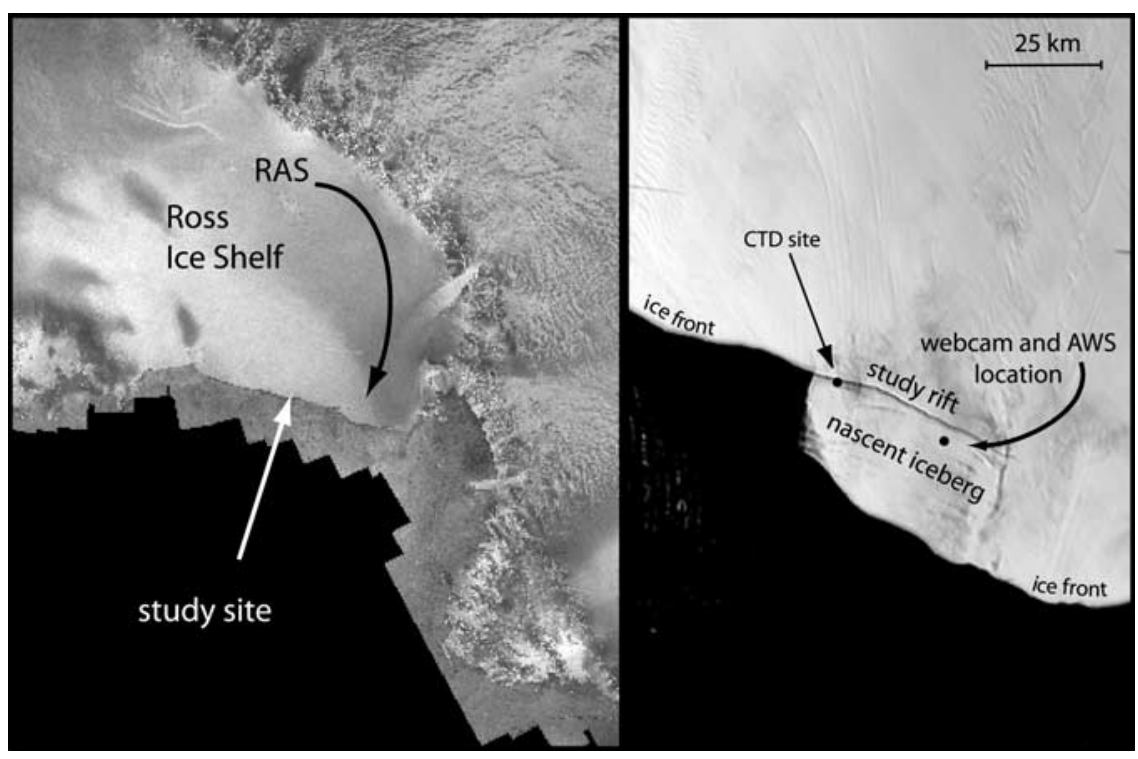

Figure 1. Location map of study site: (left) overview showing the Ross Ice Shelf and the general flow of the Ross Ice Shelf Air Stream (RAS) (1997 image from Jezek and RAMP product team [2002]) and (right) an Advanced Very High Resolution Radiometer (AVHRR) close up image of the study site in 2001 [Scambos et al., 2001]. The location of the AWS in December 2007 was 78.11 South, 178.48 West.
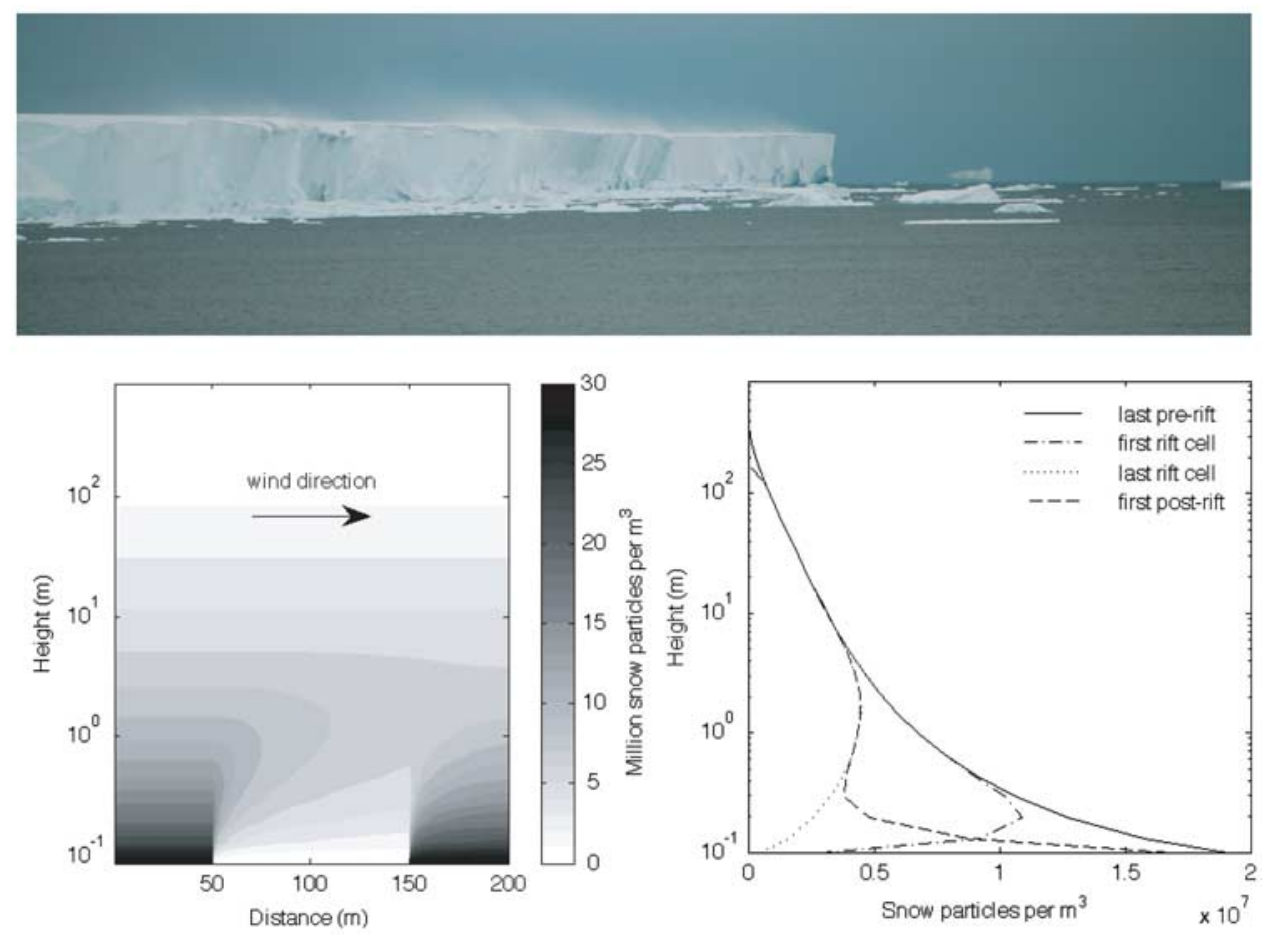

Figure 2. Wind-blown snow transport past the study rift. (top) Eastward-looking photograph of northward snow movement on the "Nascent Iceberg" taken from the Nathaniel B. Palmer, on February 10, 2007 while inside the rift. (bottom left) Modeled particle number concentration above the rift with $15 \mathrm{~m} / \mathrm{s}$ winds blowing from left to right (westward looking into page). (bottom right) Vertical profiles from individual locations within the model domain. 
winter at Halley Station [Mann et al., 2000]. Summerseason webcam pictures from November 2004 to February 2005 suggest that drifting snow was present most of the time near the rift, while blowing snow was infrequent.

\section{Atmospheric Boundary Layer Blowing Snow Model}

[7] The model employed in this study was initially developed to simulate the transport of blowing snow over Arctic sea ice. It treats the 2-D temporal evolution of a sublimating snow-filled air column over a snow-covered surface [Déry and Tremblay, 2004], based on the bulk version of a blowing snow model [Déry and Yau, 1999]. The model recognizes inhomogeneous surface conditions such as snowdrifts, sastrugi, and leads, and the effects of boundary layer stability. It integrates 4 advection-diffusion equations of the form:

$$
\frac{\partial A}{\partial t}+U \frac{\partial A}{\partial x}=\frac{\partial}{\partial z}\left(K_{A} \frac{\partial A}{\partial z}+v_{t} A\right)+S_{A}
$$

where $A$ stands for one of four prognostic variables: the blowing snow mixing ratio $q_{b}\left(\mathrm{~kg}_{\text {snow }} / \mathrm{kg}_{\text {air }}\right)$, the particle concentration of blowing snow $N\left(\mathrm{~m}^{-3}\right)$, air temperature $T_{a}$ $(\mathrm{K})$ and the water vapor mixing ratio $q_{v}\left(\mathrm{~kg}_{\text {vapor }} / \mathrm{kg}_{\text {air }}\right)$. These are integrated in time (s) and along the horizontal and vertical coordinates $x$ and $z(\mathrm{~m})$. The vertical wind profile $U$ is specified from the 10-m wind speed, roughness length, and a stability function for momentum. $K_{A}$ is the eddy diffusivity coefficient for each variable, $v_{t}$ the size-dependent terminal velocity for snow particles (zero for $T_{a}$ and $q_{v}$ ), and $S_{A}$ a source or sink term for each prognostic.

[8] Model output provides the evolution of snow thickness $h(\mathrm{~m})$ on the ice shelf and the floor of the rift from the balance between the turbulent upward mass flux and settling velocity. The transport rate of blowing snow $Q_{t},\left(\mathrm{~kg} \mathrm{~m}^{-1} \mathrm{~s}^{-1}\right)$ is the product of the blowing snow mixing ratio $q_{b}$ and the wind velocity integrated over the atmospheric boundary layer. A third diagnostic is the rift's snow trapping efficiency,

$$
T_{\text {eff }}=1-\frac{Q_{t}^{\text {out }}}{Q_{t}^{\text {in }}}
$$

where $Q_{t}^{\text {in }}$ and $Q_{t}^{\text {out }}$ are the transport rates of blowing snow above the first and last meter of the region of flow separation.

[9] The wind speed threshold for snow transport is dependent on snow surface morphology, but the model assumes that saltating snow is present, and parameterizes conditions under which drift evolves into blowing snow following $L i$ and Pomeroy [1997]. As the model does not include a snowpack density, snow is cycled between surface and air with the single-crystal density of ice $\left(900 \mathrm{~kg} \mathrm{~m}^{-3}\right)$ rather than a bulk density of snow $\left(300 \mathrm{~kg} \mathrm{~m}^{-3}\right)$ or firn $\left(600 \mathrm{~kg} \mathrm{~m}^{-3}\right)$.

[10] The vertical domain of the model runs from $0.1 \mathrm{~m}$ (assumed upper limit of the saltation layer) to $1.0 \mathrm{~km}$ above the snow surface. The threshold wind speed for saltation is lower than that for blowing snow, so the model calculates a saltating mass flux $Q_{\text {salt }}$ following Pomeroy and Gray [1990] as a source term for the base of the blowing snow column. At the lower model boundary, $q_{b}$ and $N$ are extrapolated from their values at the top of the saltation layer when the $10 \mathrm{~m}$ wind speed exceeds the threshold for blowing snow con- ditions (just below $7 \mathrm{~m} \mathrm{~s}^{-1}$ for a temperature of $-25 \mathrm{C}$ ). In regions of separation (i.e., in the lee of a steep obstacle or iceshelf wall, defined as any slope greater than 9 degrees), the flow will detach from the surface, which is no longer a source of blowing snow, and both $q_{b}$ and $N$ at that boundary become zero, despite the presence of snow on the ground. The saltation layer is assumed to be saturated, with the watervapor mixing ratio $q_{v}$ set to the saturation point for vapor above ice.

\section{Model Experiments}

[11] To determine the rate of infilling of the rift, each temperature and wind speed combination was modeled over a flat domain with periodic boundary conditions and unlimited snow supply until the four prognostic variables $\left(N, q_{b}, q_{v}\right.$ and $\left.T\right)$ reached steady state. These steady state profiles became the upstream boundary conditions for longer runs over a $100 \mathrm{~m}$ wide rift, with a $30 \mathrm{~m}$ deep floor [Fricker et al., 2005b] that only responds to snow deposition. We show results from simulations at $-25 \mathrm{C}$ and wind speeds of $5-25 \mathrm{~m} \mathrm{~s}^{-1}$. The distribution of snow particles $(N)$ above the rift is shown in the bottom plots of Figure 2. The blowing snow mixing ratio $\left(q_{b}\right)$ follows a similar pattern.

[12] Snow that falls out of the air column over the rift is concentrated at the upwind side of the rift, forming a drift 'apron' [MacAyeal et al., 2007]. This includes all snow in the saltation layer, and much of the coarse snow in suspension above. The topography of the rift snow deposit evolves over time (Figure 3, top). Once the first meter of the domain is filled to a height at which the wind can re-attach to the surface, peak deposition shifts northward until $2300 \mathrm{~m}^{3}$ of snow per $\mathrm{m}$ cross section allow complete wind reattachment.

[13] The steady-state blowing snow mass flux $Q_{t}$ is approximately scaled with the 5 th power of wind speed (Figure 3, bottom). Over the topography of the rift, $Q_{t}$ evolves with distance down-flow in a manner corresponding to the particle profiles in Figure 2. The trapping efficiency of the rift (Equation (2)) declines with decreasing rift width and increasing wind speed, which entrains snow to greater heights, keeping it in suspension across the rift. However, snow capture by the rift increases with wind speed, due to the rising transport rate. The saltating mass flux $Q_{\text {salt }}$ increases linearly with wind speed, providing a significant percentage of the total mass flux at lower speeds. While the flux of snow transported via saltation is small relative to that during a high-speed blowing snow event, the time over which saltation occurs is much greater.

[14] The time required to fill the rift with snow is a function of its trapping efficiency, higher at lower wind speeds, and the blowing snow mass transport, greater at high wind speeds. For unlimited snow supply at constant wind speeds, rift-filling time scales range between tens of days with $25 \mathrm{~m} \mathrm{~s}^{-1}$ winds to several years at $7 \mathrm{~m} \mathrm{~s}^{-1}$. These rates decrease proportionally at infill bulk densities lower than $900 \mathrm{~kg} \mathrm{~m}^{-3}$.

\section{Observations}

[15] Between November 2004 and November 2007, the average annual air temperature near the rift (Figure 1) was 

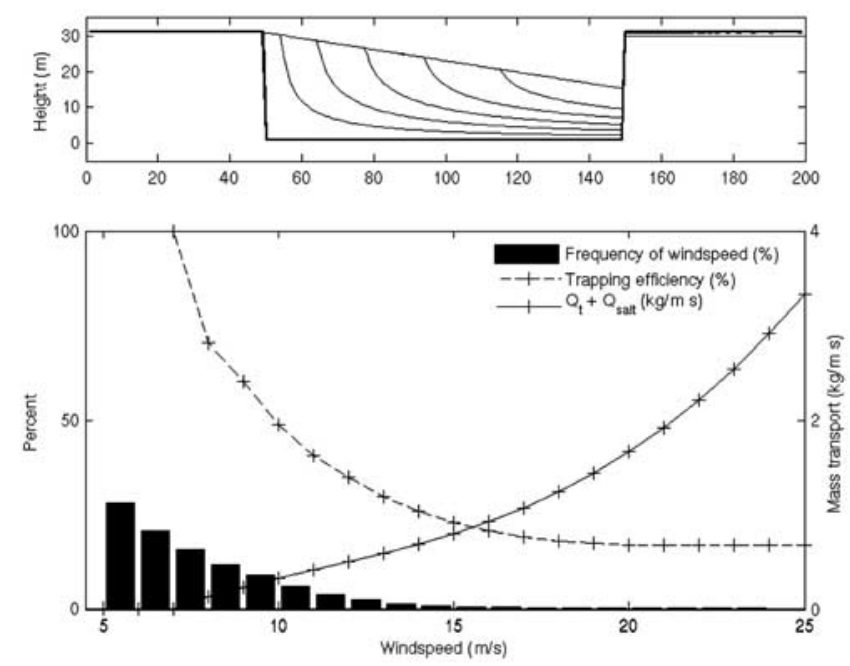

Figure 3. Sensitivity of rift-filling timescales to transport rate and trapping efficiency. (top) Evolution of topography (m) inside the rift (heavy line) over the course of one simulation. With wind equal to $25 \mathrm{~m} / \mathrm{s}$ and air temp equal to $-20 \mathrm{C}$, each solid line represents 250 hours of blowing snow. For an $8 \mathrm{~m} / \mathrm{s}$ model run, each curved line would approximate one year of deposition. (bottom) Relationship between trapping efficiency (dashed line) of a $100 \mathrm{~m}$ wide rift and blowing snow mass transport (solid line) with respect to wind speed, and the frequency distribution of wind speeds above $5 \mathrm{~m} / \mathrm{s}$ recorded by the AWS on the nascent iceberg.

$-25 \mathrm{C}$, and the average wind speed was $5.47 \pm 2.96 \mathrm{~m} \mathrm{~s}^{-1}$. The AWS recorded winds at or above the $7 \mathrm{~m} \mathrm{~s}^{-1}$ blowing snow threshold $26 \%$ of the time (Figure 3, bottom), with winter season winds as high as $24 \mathrm{~m} \mathrm{~s}^{-1}$ (20 minute average values). This suggests even higher wind speeds during gusts, particularly during winter when other ice shelf weather stations indicate a wider influence of the RAS. During the years this rift has existed, the cumulative time it has experienced winds greater than $20 \mathrm{~m} \mathrm{~s}^{-1}$ may be short, but episodic high winds can transport much of the snow into the rift. If snow were available for transport $25 \%$ of the time that wind speeds are above the $5 \mathrm{~m} \mathrm{~s}^{-1}$ drift threshold, average measured wind speeds are representative, and the bulk density of the deposited material is $450 \mathrm{~kg} \mathrm{~m}^{-3}$ (mid- way between snow and firn), a $100 \mathrm{~m}$ wide rift would fill in eight years.

[16] Seawater near the ice mélange was well above the melting temperature in early February 2007 (Figure 4). If this is representative of summer conditions, and the winter water temperature is near freezing, the average annual temperature of water in contact with the base of the mélange could be enough above the freezing point to melt $2.5-3.5$ meters of ice per year.

\section{Discussion}

[17] Our modeling results indicate the rift should now be full, assuming a flat, impenetrable rift floor and reasonable
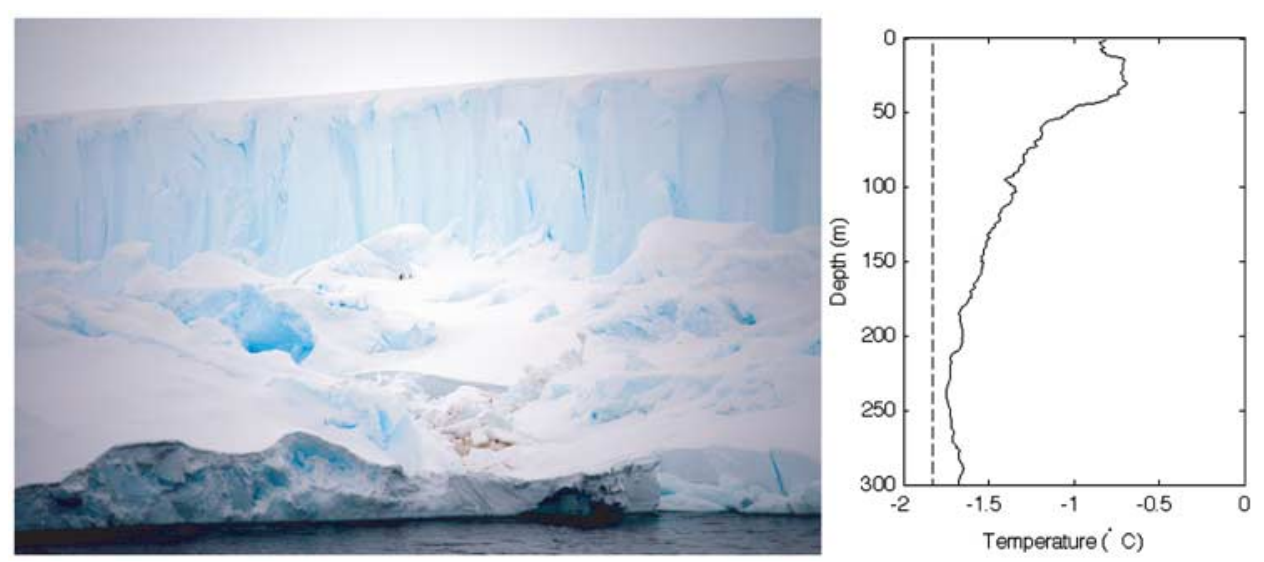

Figure 4. (left) Photograph taken during CTD station 18 (right) of cruise NBP07-02, on February 10, 2007. The ocean temperature profile was located approximately $100 \mathrm{~m}$ from the mélange edge, and the ice cliff in the background of the photograph is approximately $30 \mathrm{~m}$ high, while the Adelie penguins in the mid-distance are around $0.5 \mathrm{~m}$ tall. The brown outcrop in the foreground is interpreted as ice algae exposed by block rotation during differential subsidence of the ice mélange. (right) The temperature of seawater within the rift (solid line) was more than one degree above the surface freezing temperature (dashed line) at a surface salinity of 33.8 in the upper $50 \mathrm{~m}$. 
estimates of wind speed, snow availability, and transport. Similarly, analysis of daily webcam photographs from the summer of 2004-2005 found a snow deposition rate of $4 \pm 1 \mathrm{~m} \mathrm{a}^{-1}$ averaged across the rift [MacAyeal et al., 2007], which would fill the solid-floored model rift to the flow-separation criteria in less than 6 years. In addition to snow input, photographs indicate that cornices and other ice falls from the rift sidewalls also contribute to its mélange (Figure 4). In apparent contradiction to those results and observations, fieldwork at the rift and a visit to its open end in February 2007 by the Nathaniel B. Palmer demonstrated that its variable topography has not been overwhelmed by snow since iceberg B15 broke away from the Ross Ice Shelf along this same rift in early 2000.

[18] Photographic analyses [MacAyeal et al., 2007] suggest that the rates of subsidence of mélange $\left(5 \pm 2 \mathrm{~m} \mathrm{a}^{-1}\right)$ and widening of the rift $\left(5 \pm 2 \mathrm{~m} \mathrm{a}^{-1}\right)$ are within the range necessary to balance the input of wind-blown snow. A relatively constant mélange topographic profile may be maintained due to a hydrostatic balance between the weight of newly-deposited snow and ice and its melting into the seawater below. Widening, seawater flooding, and ice falls could rotate ice blocks, revealing layers of ice algae (Figure 4).

[19] The idea that mélange may temporarily cement icebergs to ice shelves prompted the assumption of a solid rift floor, but our results suggest this is implausible, and that mélange is less mechanically competent than previously thought. In the absence of seasonal access to "warm" ocean water - e.g. at locations further from ice fronts, mélange may grow at rates sufficient to fill ice shelf rifts, both through the input of windblown snow and the accumulation of marine ice from below.

[20] Additional field studies and autonomous year-round observations would further enhance our understanding of ice mélange processes. Such work might include time series measurements of winds and snow transport at several heights on both sides of rifts, cores of mélange, year round observations of seawater properties beneath the mélange, and studies in crevasses and rifts closer to grounding lines than ice fronts.

[21] Acknowledgments. This work was supported in part by NSF grants OPP-0229546, OPP-0230028, OPP-0230325, ANT04-40775, ARC0520496, and an NSERC Discovery grant. We thank the RPSC and ECO support personnel at McMurdo Station and aboard the Nathaniel B. Palmer. Discussions with J. Bassis, A. Clifton, R. Cullather, S. Déry, H. Fricker, A. Monaghan, K. Newyear, R. Ross, J. Thom, and J.-L. Tison contributed to this work, as did the comments of three anonymous reviewers. This is Lamont-Doherty Earth Observatory contribution 7116.

\section{References}

Carrasco, J. F., and D. H. Bromwich (1993), Satellite and automatic weather station analyses of katabatic surges across the Ross Ice Shelf, in Antarctic Meteorology and Climatology: Studies Based on Automatic Weather Sta- tions, Antarctic Res. Ser., vol. 61, edited by D. H. Bromwich and C. R. Stearns, pp. 93-108, AGU, Washington, D. C.

Déry, S. J., and L.-B. Tremblay (2004), Modeling the effects of wind redistribution on the snow mass budget of polar sea ice, J. Phys. Oceanogr., 34, 258-271.

Déry, S. J., and M. K. Yau (1999), A bulk blowing snow model, Boundary Layer Meteorol., 93, 237-251.

Fricker, H. A., N. W. Young, R. Coleman, J. N. Bassis, and J.-B. Minster (2005a), Multi-year monitoring of rift propagation on the Amery Ice Shelf, East Antarctica, Geophys. Res. Lett., 32, L02502, doi:10.1029/ 2004GL021036.

Fricker, H. A., J. N. Bassis, B. Minster, and D. R. MacAyeal (2005b), ICESat's new perspective on ice shelf rifts: The vertical dimension, Geophys. Res. Lett., 32, L23S08, doi:10.1029/2005GL025070.

Hulbe, C. L., E. Rignot, and D. R. MacAyeal (1998), Comparison of iceshelf creep flow simulations with ice-front motion of Filchner-Ronne Ice Shelf, Antarctica, detected by SAR interferometry, Ann. Glaciol., 27, $182-186$.

Hulbe, C. L., D. R. MacAyeal, G. H. Denton, J. Kleman, and T. V. Lowell (2004), Catastrophic ice shelf breakup as the source of Heinrich event icebergs, Paleoceanography, 19, PA1004, doi:10.1029/2003PA000890.

Jezek, K., and RAMP product team (2002), RAMP AMM-1 SAR image mosaic of Antarctica. Fairbanks, AK: Alaska Satellite Facility, http:// nside.org/data/ramp/, Natl. Snow and Ice Data Cent., Boulder, Colo.

King, J. C., and J. Turner (1997), Antarctic Meteorology and Climatology, 425 pp., Cambridge Univ. Press, New York.

Larour, E., E. Rignot, and D. Aubry (2004), Modelling of rift propagation on Ronne Ice Shelf, Antarctica, and sensitivity to climate change, Geophys. Res. Lett., 31, L16404, doi:10.1029/2004GL020077.

Li, L., and J. W. Pomeroy (1997), Estimates of threshold wind speeds for snow transport using meteorological data, J. Appl. Meteorol., 36, $205-213$.

MacAyeal, D. R., K. Leonard, L.-B. Tremblay, R. Ross, and J. Thom (2007), Blowing snow as a source of ice-shelf rift-filling mélange, paper presented at the International Symposium on Snow Science, Int. Glaciol. Soc., Moscow, 5-9 Sep.

Mahesh, A., R. Eager, J. R. Campbell, and J. D. Spinhirne (2003), Observations of blowing snow at the South Pole, J. Geophys. Res., 108(D22), 4707, doi:10.1029/2002JD003327.

Mann, G. W., P. S. Anderson, and S. D. Mobbs (2000), Profile measurements of blowing snow at Halley, Antarctica, J. Geophys. Res., 105, $24,491-24,508$

Parish, T. R., J. J. Cassano, and M. W. Seefeldt (2006), Characteristics of the Ross Ice Shelf air stream as depicted in Antarctic Mesoscale Prediction System simulations, J. Geophys. Res., 111, D12109, doi:10.1029/ 2005JD006185.

Pomeroy, J. W., and D. M. Gray (1990), Saltation of snow, Water Resour. Res., 26, 1583-1594.

Rignot, E., and D. R. MacAyeal (1998), Ice-shelf dynamics near the front of the Filchner-Ronne Ice Shelf, Antarctica, revealed by SAR interferometry, J. Glaciol., 44, 405-418.

Rott, H., P. Skvarca, and T. Nalger (1996), Rapid collapse of northern Larsen Ice Shelf, Antarctica, Science, 271, 788-792.

Scambos, T. A., C. Hulbe, M. Fahnestock, and J. Bohlander (2000), The link between climate warming and break-up of ice shelves in the Antarctic Peninsula, J. Glaciol., 46, 516-530.

Scambos, T., J. Bohlander, and B. Raup (2001), Images of Antarctic ice shelves, http://nsidc.org/data/iceshelves_images/, Natl. Snow and Ice Data Cent., Boulder, Colo.

Schwerdtfeger, W. (1984), Weather and Climate of the Antarctic, 261 pp., Elsevier, New York.

S. S. Jacobs and K. C. Leonard, Lamont-Doherty Earth Observatory, P.O. Box 1000, Palisades, NY 10964, USA. (kleonard@1deo.columbia.edu)

D. R. MacAyeal, Department of Geophysical Sciences, University of Chicago, 5734 S. Ellis Avenue, Chicago, IL 60637, USA.

L.-B. Tremblay, Department of Atmospheric and Oceanic Sciences, McGill University, Montreal, QC H3A 2K6, Canada. 